University of Nebraska - Lincoln

DigitalCommons@University of Nebraska - Lincoln

To Improve the Academy

Professional and Organizational Development Network in Higher Education

1996

Who Uses Faculty Development Services?

Nancy Van Note Chism

Borbala Szabo

Follow this and additional works at: https://digitalcommons.unl.edu/podimproveacad

Part of the Higher Education Administration Commons

Van Note Chism, Nancy and Szabo, Borbala, "Who Uses Faculty Development Services?" (1996). To Improve the Academy. 353.

https://digitalcommons.unl.edu/podimproveacad/353

This Article is brought to you for free and open access by the Professional and Organizational Development Network in Higher Education at DigitalCommons@University of Nebraska - Lincoln. It has been accepted for inclusion in To Improve the Academy by an authorized administrator of DigitalCommons@University of Nebraska - Lincoln. 
Chism, N.V.N., \& Szabó, B. (1996). Who uses faculty development services? In L. Richlin (Ed.), To Improve the Academy, Vol. 15 (pp. 115-128). Stillwater, OK: New Forums Press and the Professional and Organizational Development Network in Higher Education. Key words: Faculty Development, Faculty Development Role, Instructional Development, Needs Assessment.

\section{Who Uses Faculty Development Services?}

\section{Nancy Van Note Chism}

\section{Borbála Szabó}

The Ohio State University

Information about who uses faculty development services exists more in the oral tradition than in the literature. This study sought to explore the question systematically, based on a review of the literature and the conducting of a descriptive survey of faculty development programs. The findings of the study show that most programs collect information on their users, that this information is usually not shared publicly, and that aggregate usage is broad-based, rather than concentrated within particular types of faculty. These findings contradict some popular claims and support others. Recommendations suggest that information be collected systematically and that claims about users be based on data.

Faculty developers are accustomed to hearing statements about the characteristics of the users of their services. Some routinely make such generalizations themselves. A commonplace observation is that faculty developers "preach to the converted," that is, they serve mainly those faculty who are already good teachers and have an interest in teaching. In apparent contradiction to this statement, the claim that 
faculty developers are remediators who concentrate on faculty with significant teaching problems is also frequently made.

Other statements about users address their various characteristics, such as their disciplinary background, often positing that faculty in some disciplines (the sciences are frequently singled out) are less likely to use services than those in other disciplines; their rank, often asserting that assistant professors are more heavy users than full professors; or their gender, saying that females are more likely to use services than males. Observations are also made about how heavily services are used. What seems to characterize most of these observations is that the data sources upon which they are based are not made explicit. This study is an attempt to look into the literature for empirical evidence on the nature of users of faculty development services and to report on the results of a survey that sought to obtain data on this topic.

\section{Claims in the Literature}

A search of the literature found assertions about the volume of use and motivation of those who use services, but hardly any information about other characteristics. One can conclude, then, that many claims are more from the oral than written tradition. When one looks at the written claims, it is hard to unravel the chain of evidence supporting the statements. Boice (1984), for example, says that "faculty developers tend to reach faculty least in need of help" (p. 195), Boice also cites a study by Centra, 1978. In a fuller research report Centra (1976), Centra does report that faculty development programs serve good teachers, but also finds that at $52 \%$ of the institutions he surveyed, faculty who "really need to improve" are participating in the programs to some degree.

In another paper, Angelo (1994) states, “. . . first, a relatively small percentage of faculty take advantage of the programs; second, those faculty who do participate are often the ones who seem to need them the least" (p. 3). He alludes to "survey research and my own talks with practitioners" (p. 3) as backing for his claims. In conjunction with the survey research, he cites Maxwell and Kazlauskas (1992): "These [faculty development] programs... muster only moderate or even little 
participation, often are relatively ineffective, and have particularly little impact on those who most need to improve their teaching" (p. 352).

In the Maxwell and Kazlauskas paper, the authors base their conclusions about usage primarily on fairly dated studies done in widely differing types of institutional settings, although the authors focus on the community college setting, which is their main interest. Several of the studies are reports of faculty surveys that asked respondents to indicate their "preferences for further preparation" (Cohen \& Brawer, 1977, p. 72), "need for improvement by colleagues or self" (Blackburn, Boberg, O’Connell, \& Pellino, 1980), or their preferences for a development program, so they are based on broad attitudinal predisposition data rather than actual usage data. In the Blackburn et al. (1980) study, the questionnaire in the appendix asks for participation data, but this is not reported in such a way as to determine which faculty used which services.

Maxwell and Kazlauskas also rely heavily on the summary of Centra's 1976 study (Centra, 1978). In this national survey, faculty development program coordinators were asked to estimate the proportion of faculty at their institution who used each of the services in a list he supplied. The general finding was that out of the five categories of services Centra listed, those typically provided by faculty development programs, such as consultation on course design, help with teaching methods, and workshops on teaching practices, were the most widely used by faculty. As discussed above, Centra also reported usage based on categories of faculty participants he listed, finding that while respondents reported that faculty from his category "good teachers who want to get better" participate in programs to a great degree, faculty "who really need to improve" are also participating to some extent, although this rate is lower.

Other studies, such as Hoyt and Howard (1978), do not cite sources for their claims, so it is hard to find actual data. This lack of data prompted the survey undertaken for this study.

\section{The Survey}

The survey set out to obtain data to answer two main research 
questions: who uses the services of faculty development programs? and how do the programs evaluate their services? This report will focus only on the first question. The full research report (Chism \& Szabó, 1996) can be obtained on request.

The survey instrument was developed interactively with fifteen reviewers from the Professional and Organizational Development (POD) Network in Higher Education, the major professional organization serving faculty developers. It was then pilot tested with six institutions and revised. A random sample of the POD membership list was drawn after duplicate institutions and international programs were eliminated. One hundred institutions received Form $\mathrm{A}$ of the survey, which focused on the first research question concerning users of services. The response rate was $52 \%$. Respondents were distributed across Carnegie classification, public/private support, and size. Characteristics of their institutions and programs are contained in Table 1.

\begin{tabular}{|l|c|}
\hline \multicolumn{2}{|c|}{ TABLE 1 } \\
Descriptive Characteristics of Faculty \\
Development Respondents \\
\hline Characteristic & Percentage \\
\hline Carnegie classification: & 14.9 \\
Research I or II & 14.9 \\
Doctoral I or II & 31.9 \\
Comprehensive I or II & 12.8 \\
Liberal arts I or II & 10.6 \\
Community, junior or technical college & 2.1 \\
Prof. school or other specialized institution & 6.4 \\
International or other Non-Carnegie classification & 6.4 \\
Other & \\
\hline Control: & 61.7 \\
Public & 36.2 \\
Private & \\
\hline Type of structure: & 10.6 \\
Faculty committee & 38.3 \\
Individual faculty member & 44.7 \\
Organizational unit & 6.4 \\
Other &
\end{tabular}




\begin{tabular}{|c|c|c|c|}
\hline $\begin{array}{l}\text { Potential clients: } \\
\text { Full-time faculty } \\
\text { Part-time faculty } \\
\text { Teaching assistants (total sample) } \\
\text { Teaching assistants (only respondents who had) } \\
\text { Other: (administrators, library staff etc.) } \\
\end{array}$ & \begin{tabular}{|l|} 
Range \\
$16-2500$ \\
$0-2000$ \\
$0-2500$ \\
$10-2500$ \\
$6-5500$ \\
\end{tabular} & \begin{tabular}{|l|} 
Mean \\
572 \\
219 \\
224 \\
459 \\
290 \\
\end{tabular} & \begin{tabular}{|l|} 
Median \\
373 \\
150 \\
0 \\
200 \\
37 \\
\end{tabular} \\
\hline $\begin{array}{l}\text { FTE of organizational units: } \\
\text { FTE }\end{array}$ & $\begin{array}{l}\text { Range } \\
.33-10 \\
\end{array}$ & \begin{tabular}{|l|} 
Mean \\
2.2
\end{tabular} & $\begin{array}{l}\text { Median } \\
1.5 \\
\end{array}$ \\
\hline $\begin{array}{l}\text { Program reports to: } \\
\text { Academic affairs } \\
\text { Dean of academic unit } \\
\text { Media center } \\
\text { Research unit } \\
\end{array}$ & \multicolumn{3}{|c|}{$\begin{array}{l}\text { Percentage } \\
95.7 \\
0.0 \\
0.0 \\
4.3\end{array}$} \\
\hline $\begin{array}{l}\text { Dedicated space for program: } \\
\text { Yes } \\
\text { No }\end{array}$ & \multicolumn{3}{|c|}{$\begin{array}{c}\text { Percentage } \\
80.9 \\
19.1 \\
\end{array}$} \\
\hline \begin{tabular}{|l} 
Months program in operation: \\
12 \\
11 \\
10 \\
9 \\
Other or Missing \\
\end{tabular} & \multicolumn{3}{|c|}{$\begin{array}{c}\text { Percentage } \\
59.6 \\
4.3 \\
12.8 \\
14.9 \\
8.5 \\
\end{array}$} \\
\hline $\begin{array}{l}\text { Services provided by the unit: } \\
\text { Workshops } \\
\text { Seminars } \\
\text { Publications } \\
\text { Orientations } \\
\text { Grants } \\
\text { Serving as resource person to instructional project } \\
\text { Consultations } \\
\text { Classroom observation } \\
\text { Lecture series } \\
\text { Videotaping } \\
\text { Helping with research on teaching/learning } \\
\text { Class midterm interviews } \\
\text { Helping with instructional programevaluation } \\
\text { Teaching awards programs } \\
\text { Mentoring programs } \\
\text { Conducting research on teaching/learning } \\
\end{array}$ & \multicolumn{3}{|c|}{$\begin{array}{c}\text { Percentage } \\
97.9 \\
89.4 \\
87.2 \\
80.6 \\
76.6 \\
74.5 \\
72.3 \\
66.0 \\
63.8 \\
55.3 \\
53.2 \\
36.2 \\
31.9 \\
29.8 \\
29.8 \\
29.8\end{array}$} \\
\hline
\end{tabular}

\section{Documentation of Usage}

Respondents to Form A were asked if they keep records on who uses their services, and if so, the approximate number of people they 
serve; how these users are distributed across categories of job title, gender, and discipline; and why their users seek out their services.

User record keeping practices are displayed in Table 2.

\begin{tabular}{|c|c|c|c|}
\hline \multicolumn{4}{|c|}{$\begin{array}{c}\text { TABLE } 2 \\
\text { Record keeping Practices of Faculty Development Units } \\
\text { (In percentages) }\end{array}$} \\
\hline $\begin{array}{l}\text { Of those who have } \\
\text { the service... }\end{array}$ & $\begin{array}{c}\text { Keep user records } \\
\text { routinely }\end{array}$ & $\begin{array}{l}\text { Keep user records } \\
\text { sometimes }\end{array}$ & $\begin{array}{l}\text { Never keep user } \\
\text { records }\end{array}$ \\
\hline Events & 71.8 & 19.6 & 8.9 \\
\hline Consultations & 68.4 & 21.1 & 10.5 \\
\hline Publications & 62.5 & 27.5 & 10.0 \\
\hline Mentor program & 86.9 & 13.1 & 0.0 \\
\hline
\end{tabular}

Results show that there is a generally high level of record keeping within faculty development programs, indicating that the question of who uses services can indeed be answered empirically. When one looks at the reported rates of user documentation, the high rate for mentor programs would be expected, given that mentoring arrangements are usually formally recorded. The rate on consultations, although somewhat high, is lower than might be expected. Unless respondents included casual conversations in this category, one would think that consultation records are always kept. The high record keeping rate for events indicates that most of the time there is a registration or sign-in procedure that enables development staff to keep track of attendees. The publication distribution record keeping rate is higher than expected, given that one might expect newsletters, handbooks, and other publications to be disseminated through batch methods rather than individual labels. Perhaps in many cases, these are distributed to entire populations for which there is a directory, and thus usage is trackable. On the whole, there is evidence to conclude that most programs, no matter what structure or staff size, take record keeping seriously and have data about their users.

\section{Numbers of Users}

For those respondents who keep data on their users, the approxi- 
mate number of users per 12-month period they reported for each of the categories of service listed in the survey are displayed in Table 3.

\begin{tabular}{|l|c|c|c|c|}
\hline \multicolumn{5}{|c|}{ TABLE 3 } \\
Numbers of Users of Faculty Development Services \\
\hline $\begin{array}{l}\text { For programs that } \\
\text { provide these services... }\end{array}$ & Range & Mean & Median & $\begin{array}{c}\text { Mean usage rate } \\
\text { (potential clients } \\
\text { vs. usage) }\end{array}$ \\
\hline Event users & $45-2500$ & 381.5 & 200 & $47 \%$ \\
\hline Consultation users & $5-387$ & 87.6 & 50 & $11 \%$ \\
\hline Publication users & $10-5000$ & 774.1 & 350 & $82 \%$ \\
\hline Mentor program users & $2-160$ & 47.7 & 20 & $8 \%$ \\
\hline
\end{tabular}

Although the ranges are broad since the potential client base is broad, these data suggest relatively high use of faculty development services. When reported total usage was analyzed as a percentage of client base to produce a usage rate, the range of percentages varied widely, indicating that there is quite a diversity of rates from one institution to another. The mean usage rates show that publications reach most potential users, followed by events, consultations, and mentoring programs. The rates for events and consultations should not be strictly interpreted as percent of total client base who use the service, since users of multiple services are likely in these figures. The rates for publications and mentoring were provided on a user, rather than usage, basis.

Some patterns of usage were associated with institutional size. (Institutions were categorized as small when the potential client base was under 500, medium if it was between 500 and 1000, and large if it was equal to or greater than 1000.) Small institutions reported reaching more of their client base through events than larger institutions, but consultations were associated more with larger institutional size, since many small institutions did not provide consultation services. Smaller institutions also reported higher rates of publication dissemination (93.5\%), although the rate for medium and large institutions was still high ( $72.6 \%$ and $68.6 \%$, respectively). 


\section{Types of Users}

Respondents were asked if they are able to describe characteristics of their users, and if so, to complete a grid that asked for percentage breakdowns by job title, gender, and disciplinary cluster. A total of 42.6 percent of the respondents were able to provide percentages for title, 40.4 percent for gender, and 46.8 percent for discipline. Faculty development programs with more than one full-time equivalent (FTE) staff member were able to provide this data at significantly higher levels than those with less than one FTE committed to faculty development, which may indicate the importance of staffing in record keeping. Distribution of users according to these characteristics are displayed in Table 4. (This is likely to be more reflective of the large programs that have data than the smaller programs that could not answer this item.)

\begin{tabular}{|c|c|c|c|c|c|c|}
\hline \multicolumn{7}{|c|}{$\begin{array}{c}\text { TABLE } 4 \\
\text { Characteristics of Users of Faculty Development (In } \\
\text { percentages) }\end{array}$} \\
\hline \multirow{2}{*}{\begin{tabular}{|l|} 
Demographic Categories \\
Title:
\end{tabular}} & \multirow{3}{*}{\begin{tabular}{|l|} 
Range \\
0.60
\end{tabular}} & \multirow{3}{*}{$\begin{array}{l}\text { Mean } \\
21.7\end{array}$} & \multirow{3}{*}{\begin{tabular}{|l|} 
Median \\
20.0
\end{tabular}} & \multicolumn{3}{|c|}{$\begin{array}{c}\text { For those who don't } \\
\text { have TAs }\end{array}$} \\
\hline & & & & Range & Mean & Median \\
\hline Full professor & & & & & 26.5 & 30.0 \\
\hline & $10-40$ & 24.1 & 25.0 & $18-40$ & 27.3 & 27.5 \\
\hline Assist & $10-40$ & 27.1 & 27.5 & $0-40$ & 26.3 & 27.5 \\
\hline Nonte & $5-95$ & 23.5 & 10.0 & $5-95$ & 41.3 & 25.0 \\
\hline Teac & $0-40$ & 13.6 & 5.0 & $0-15$ & 7.8 & 10.0 \\
\hline Adminis & $0-1$ & 7.6 & 10.0 & & & \\
\hline \multicolumn{7}{|l|}{ Gender: } \\
\hline Female & & 48.7 & 50 & & & \\
\hline Male & $20-90$ & 51.1 & 50.0 & & & \\
\hline \multicolumn{7}{|l|}{ Discipline group: } \\
\hline Arts and humanities & $1-99$ & 32.3 & & & & \\
\hline Social \& behavioral s & & 22.5 & & & & \\
\hline & & 19.23 & & & & \\
\hline Professional school & $2-100$ & 9.9 & & & & \\
\hline
\end{tabular}

As the ranges show, percentages vary dramatically from one institution to another and are very dependent on the characteristics of 
the potential clients. For example, teaching assistants are concentrated in research, doctoral, and comprehensive universities and account for up to 40 percent of the respondents' percentages in some of these schools. All entries over 25 percent for the teaching assistant category were at Research I and II institutions. The percentage of faculty users that would be reported in these institutions would then be proportionally lower. The median column shows the overall percentage across all institutions.

Given these limitations of the data, the patterns show that use is fairly evenly distributed across faculty categories, with assistant professors accounting for a somewhat higher percentage of use. The gender breakdown shows equal distribution across genders, which likely indicates that females use faculty development services at higher rates than males, since they usually account for a significantly lower percentage of total faculty than males. Use across disciplinary categories is more evenly distributed than one might expect, with only slightly lower reported use by social and behavioral and math and physical sciences than arts and humanities or professional schools.

\section{Reasons for Use of Faculty Development Services}

Respondents were asked what kind of data they keep on why their clients use their services. In response to what kind of data they keep, 31.9 percent indicated that they do not have records on why clients use their services; 36.2 percent said that consultant records would have this kind of information; 38.3 percent said that they have survey data on why clients use their services; and $27.7 \%$ said that they know that some clients use their services because they are required to do so, as in the case of mandatory attendance at TA orientations, and the like. (Percentages sum to over 100 since some respondents reported having more than one type of data.) The almost 70 percent figure for those who have data on why services are used is somewhat surprising, given that much reported use occurs through workshop participation and publication dissemination, where it would be hard to ascertain a user's reasons, except by survey of the entire population of users at some point in time, which 38.3 percent of respondents report doing.

Respondents then were asked to estimate the percentages of 
clients for whom the primary reason was each of four categories. These are displayed in Table 5.

\begin{tabular}{|l|l|c|c|c|c|c|c|}
\hline \multicolumn{7}{|c|}{ TABLE 5 } \\
Primary Reasons for Using Faculty Development \\
(In percentages) \\
\hline Reason & \multicolumn{3}{|c|}{ Estimate based on data } & \multicolumn{3}{c|}{$\begin{array}{c}\text { Estimate based on hunch } \\
\text { Range }\end{array}$} \\
& $0-30$ & 20.0 & 20 & $0-90$ & 8.70 & 0 \\
\hline Required to use & $10-60$ & 26.7 & 25 & $0-80$ & 21.0 & 20 \\
\hline $\begin{array}{l}\text { Experiencing a teaching } \\
\text { problem }\end{array}$ & $20-60$ & 40.3 & 41 & $5-100$ & 58.1 & 60 \\
\hline $\begin{array}{l}\text { Interested in exploring new } \\
\text { ideas about teaching }\end{array}$ & & & & & & \\
\hline $\begin{array}{l}\text { To validate quality of their } \\
\text { teaching }\end{array}$ & $8-40$ & 13.0 & 10 & $0-50$ & 11.9 & 10 \\
\hline
\end{tabular}

Despite the fact that nearly 70 percent of the respondents indicated that they have data on reasons for the use of their services, only 13 percent chose to answer this item based on data. Perhaps the difficulty of sorting and compiling the data for this survey led them to rely on hunch or the categories of reasons offered in the item are different from the categories that they use in keeping data. The hunch column shows the effect of one or two outlyers, such as the respondent who answered that 90 percent of their usage is required and the respondents who answered that 5 percent and 100 percent respectively of their usage is driven by interest in exploring teaching ideas. Given this, despite the low number of respondents, the data column answers might be more indicative of a pattern, except in the case of the required category, which is likely to be inflated in comparison with the other categories since requirements are a form of data and thus would show more frequently for this group. The distribution across categories shows that faculty use services for a variety of reasons, with exploring new ideas being the primary reason, and addressing a teaching problem another main reason. Those who use services to validate the quality of their teaching or because they are required to do so constitute a smaller, but not insignificant, proportion of those served. 


\section{Discussion}

A major observation that the study supports is that it is very difficult to answer the question of who uses faculty development services. Several reasons account for this difficulty:

1. Faculty development programs vary greatly in mission, composition of potential clients, and range of services offered. This makes it particularly hard to aggregate data and thus provide simple answers on the extent of faculty use across programs.

2. The data that programs collect is rarely reported publicly so it is hard to obtain data.

3. In oral tradition of answers to this question has been established and gone generally unchallenged, reducing the motivation to explore the issue.

4. The categories that are used in the oral tradition, such as "the converted," "the remedial," and "those who least need the services" are ill-defined. How would one classify users with these labels through a self-report? consultant identification?

Despite these difficulties, some observations can be made, based on this review of the literature and the survey:

1. Most faculty development programs keep records on who uses their services. Overall usage rates are thus generally known at the institutional level, although these data are generally not reported outside the institution.

2. For those programs that have data, the survey findings show that the average program reaches 82 percent of its client base with publications; 47 percent through events; 11 percent through consultation; and 8 percent through mentoring programs. The interpretation of the figures is an issue. Although these figures vary widely across institutions, on aggregate, the picture seems fairly positive and hardly consistent with claims that services are rarely used. To one expecting 100 percent participation, they appear wanting. Yet to a faculty developer, they might appear quite high. One would expect certain of these figures to be low. For example, mentoring programs are usually targeted at new teachers exclusively, so an 8 percent figure appears appropriate. Similarly, consultations are likely to be needed only occasionally by most faculty, and could be constrained by the avail- 
ability of consultants, given that most faculty development programs have few staff members.

3. Only half of the programs in the survey were able to report on specific demographic characteristics of their users. There does not seem to be current data on this in the literature either, so claims about these characteristics are likely to be based on generalizations of personal experience or expectations, which should be viewed with some caution. For those programs that reported data, some of these popular claims are supported and some are not. For example, users are distributed across faculty categories (and across the faculty-TA distinction, for those that have TAs). Although assistant professors account for a higher percentage of users, associate and full professors are well represented in the client base. This finding contradicts popular claims that experienced faculty do not use services (which Centra, 1976, earlier refuted, although he found relatively greater use by younger faculty). When one looks at the data on gender breakdown, there is some support for the popular belief that female faculty are more likely to use services than males. There is less support for the belief that certain disciplines are heavy users of services than others. Although the survey showed slight differences, they are not extreme.

4. The reasons for using faculty development services are also varied. Although the results from the survey are constrained by such limitations as response rate and the categories that were used, there is some support for the claim that faculty are motivated both by interest in teaching and by difficulties. This finding is consistent with Centra's 1976 study for those categories that are comparable across the two surveys. It contradicts popular claims that there are unidimensional reasons, either remedial or reinforcing. It does, however, leave unanswered the question of whether the services reach "those who need them most, "since it is quite hard to define this group. If the descriptor refers to the hostile or those with severe teaching problems, these faculty would appear to be a subset of the survey category "experiencing a teaching problem," which accounts for about one quarter of the users reported by respondents who answered this item, a finding that would not support wholesale claims that those most in need of services do not participate in faculty development, but would not rule out the 
possibility that some do not, given that more than a quarter of the faculty might be experiencing teaching problems in a given year.

\section{Recommendations}

Although the review of the literature and survey undertaken for this study shed some light on the question of who uses faculty development services, the nature of the question itself remains problematic and requires reformulation and additional study. Some recommendations that can be made at this time follow:

1. Claims about who uses faculty development services should be based on data. Overgeneralization and statements based on rumor should be questioned.

2. Faculty development programs should be diligent in collecting information on who uses their services and should find ways of reporting this data routinely and publicly. Perhaps the main professional group for faculty developers, the Professional and Organizational Development Network in Higher Education, could coordinate a regular aggregate report based on common categories across member programs.

3. Programs should employ user data in self-assessment efforts to set goals and inform program planning.

In sum, this attempt to locate empirical information about who uses faculty development services, while limited, does argue for a more complex description than the popular claims convey. Hopefully, it will lead to more research and responsible reporting concerning the characteristics of those who are served by faculty development programs.

\section{References}

Angelo, T. A. (1994). From faculty development to academic development. Bulletin of the American Association for Higher Education, 46, 3-7.

Blackburn, R. T., Boberg, A., O’Connell, C., \& Pellino, G. (1980). Project for faculty development program evaluation: Final report. Ann Arbor, MI: Center for the Study of Higher Education, University of Michigan. (ERIC Document Reproduction Service No. ED 208 767)

Boice, R. (1984). Writerly rules for teachers. Journal of Higher Education, 66, 32-60.

Centra, J. A. (1976). Faculty development in U. S. colleges and universities. Princeton, NJ: 
Educational Testing and Services. (ERIC Document Reproduction Service No. ED $141382)$

Centra, J. A. (1978). Faculty development in higher education. Teachers College Record, 80, 188-201.

Chism, N. V. N., \& Szabó, B. (1996). Faculty development program usage and evaluation: Project report. Columbus, OH: Faculty and TA Development, The Ohio State University.

Cohen, A. M., \& Brawer, F. B. (1977). The two-year college instructor today. New York: Preager.

Hoyt, D. P., \& Howard, G. S. (1978). The evaluation of faculty development programs. Research in Higher Education, 8, 25-38.

Maxwell, W. E., \& Kazlauskas, E. J. (1992). Which faculty development methods really work in community colleges? A review of research. Community/Junior College Quarterly, 16, 351-360.

\section{Contact:}

Nancy Van Note Chism

Office of Faculty \& TA Development

The Ohio State University

20 Lord Hall

124 West 17th Avenue

Columbus, OH 43210-1316 USA

(614) 292-3644

(614) 292-3299 FAX

chism.1@osu.edu

Nancy Van Note Chism is Director of the Office of Faculty and TA Development at The Ohio State University. She is past President of the Professional and Organizational Development Network in Higher Education and serves as Coordinator of the National Consortium on the Preparation of Graduate students as College Teachers. She is an adjunct faculty member in the Ohio State College of Education, teaching courses in qualitative research and college teaching. She is coordinating the evaluation of several federally-funded projects in medicine, engineering, and art history.

Borbála Szabó is a graduate student from Budapest, Hungary, working as a graduate research assistant in the Office of Faculty and TA Development. She is pursuing a doctoral degree in the Ohio State College of Education. 